\title{
Figurative Language and Symbolism Manifested in Bukusu Cultural Songs and Proverbs
}

\author{
Aggrey Wafula Watulo, Ph.D . Applied Linguistics, Laikipia University, Nigeria \\ watuloaggrey@gmail.com
}

\begin{abstract}
The paper investigates the place of song, dance, and proverbs as manifested in selected cultural practices of the Bukusu community. Song, dance, and proverbs are notoriously utilized, with each having roots and a focus on a specific event. The study's objective includes the role, occasion, and function of such markers of culture that have been utilized during crowded festivities despite the Covid 19 pandemic. In light of this, the proposition made is that language and culture have a close interplay and promote social ties hence maintaining societal, cultural festivities like marriage, burial, circumcision, to list a few. The pandemic has thwarted the trajectory created in such rich cultural festivities. This manifestation of cultural rights is promoted in public or hidden homes to ensure that culture is passed on from one generation to another. The argument ensures that culture is promoted through linguistic ability, oratory skills, song, music, and dance to create a cohesive society, building an affluent cultural society. Culture is communicated through literary and linguistic tools such as proverbs, songs, symbolism, and propaganda, Coupled with various cultural activities in the community. The paper forms a base for an analysis of selected festivities that gained prominence amid the ravages of the pandemic. The study adopts a convenience sampling technique to identify subjects. D ata was collected through participant observation and focus group discussion of the cultural activities within Bungoma County. The participants were drawn from notorious villages that have continuously promoted the cultural festivities through crowds despite the escalating numbers of Covid 19 victims. The data will be analyzed descriptively.
\end{abstract}

Keywords: culture, song, society, proverbs, symbolism

Published: 2021-09-26

Doi: https:/ / doi.org/ 10.24127/ sociometry.v1i1.1342

\section{How to Cite:}

Watulo, A. (2021). Figurative Language and Symbolism Manifested in Bukusu Cultural Songs and Proverbs. Sociometry Journal of Social Science, Art and Humanity, 1(1).

https:/ / doi.org/ 10.24127/ sociometry.v1i1.1342

Issue: Vol 1 No 1 (2021)

Section: Articles

(c) (1)

Copyright (c) 2021 Sociometry Journal of Social Science, Art and Humanity

This work is licensed under a Creative Commons Attribution 4.0 International License. 


\section{INTRODUCTION}

Bukusu is a sub-tribe of the Abaluhya, which, in Lubukusu, means "child of one common father in a polygamous family." Bukusu is one of the seventeen sub-tribes that comprise the Abaluhya cluster of the interlacustrine Bantu nations of East Africa from the more significant Bantu-speaking people who have lived in East Africa since the first millennium A.D. The seventeen Luhya language dialects comprise: Lutiriki, Lubukusu, Luloogoli, Lunyore, Lukhayo, Lumarachi, Lusamia, Lwitakho, Lutsotso, Lukabarasi, Lutachoni, Luwanga, Lumarama, Lunyala west, Lunyala east, Lutura and Lwisukha (Angogo, 1980; Watera, 2013; Nandelenga, 2014, Watulo, 2018).

Wasambo (2009) notes that the Abaluhya, unlike their neighbors, the Luos, are not a single entity and do not constitute a homogenous group of people. Batachoni, the Bukusus inhabit Bungoma County in Kenya. The size of Bungoma County is approximately 3,074 square kilometers. It borders Kakamega to the East, Mount Elgon to the West, Trans Nzoia to the North, and Busia to the South (Wasambo, 2009). Bukusu is the largest single ethnic unit in the Luhya land, followed by the Maragoli. The dialects are classified as northem, central, and southern, with Lubukusu being categorized as northern. Lubukusu is a Bantu language spoken in Western Kenya and parts of the Rift valley. The County is divided into four divisions of 10 locations, with the highest population density in Kimilili.

Goodenough (1996) posits that culture is a clear and interactive association of individuals that possess a given way of life. Culture creates a distinction between humans and animals (Jafari and Mahadi, 2012). ON THE OTHER HAND, T. S. Eliot (1961) claims that culture is capital and away from creating all cultures and knowledge for purposes of sharing human problems, helping economic emancipation, and political stability.

Culture is not an inherent inborn and will-less aspect but a social venture (Jafari and Mahadi, 2012). They argue that culture is transmitted through societal knowledge, social change, social relations, and mass media. Given this, culture is communicated through poems, stories, fiction, epics, and myths; hence they form the main ingredients of culture (Jafari and Mahadi, 2012). Strauss (1976) looks at language as a tool that relays universal realities through symbols, and that is to say that words are the embodiment and dynamic tool of cultural symbols.

Maelo (2014) argues that the Bukusu community ritual oratory performance communicates most of the genres evident in the Bukusu society. In light of this, the performer utilizes several proverbs in his narration to reflect human society, whereby the proverbs are identifiable with the context of the ritual performance. The song, dance, and proverbs are chosen based on the ritual, context, participants, and occasion for any cultural event. Maelo (2014) argues that specialized language use creates a sense of musicality and rhythm, which is realized in the oratory through repetition hence lending a musical quality that reflects the basis of poetry tradition. The music's mastery of the content, structure, and form is vested in the ritual performer who exudes skills and knowledge of the rendition. The language utilized in such a rendition is rich in symbolism, figurative nature conveying abstract ideas.

King'ori and Naituli (2018) explain that coded language is words, phrases, and terms used by a given group of people to refer to an object, person, or group of people that the said community can only understand. Coded language is often communicated through imagery, proverbs, and idiomatic expressions, etcetera (Holtgraves and Kashima, 2009). Coded language, in Kenya, is used to exclude those they term as enemies since they do not speak the given community's language. The purpose of coding in the language is to interact freely without inconvenience then harbor negative feelings about the outsiders. Although culture is communicated through coded language, politicians have utilized such a language to gain political mileage, oratory skills, create propaganda, and hoodwink the electorates (King'ori and Naituli, 2018).

Thompson et al. (2021) report that song and music can be utilized as a means of education to create awareness in public health situations and clinical experiences. Henceforth music influences knowledge, attitudes, and behaviors towards infectious diseases like Covid 19, which is not new in African nations. It is argued that artists 
have also incorporated messages and basic details about diseases such as HIV/ AID S Ebola through song, music, and dance to caution the people to take preventive measures. It is evident that the G hanaian artists in 2000, through a campaign, 'stop AID S: Love Life, underpin the awareness about HIV/ AID S in the country to de-stigmatize HIV/ AID S and educate people to adopt good sex behavior. The notable feature of songs, such as repetition, which creates memorability and recall, enhances the effectiveness of health educational messages.

Thompson (2021) points out that songs about the coronavirus in parts of the world sought to inform the populace that the virus is actual and not a hoax, as some individuals thought. In some lyrics, the singers noted that the disease emerged from china and spread to Europe, the USA then Africa. In most countries, composers sing about the high death toll, while many people are hospitalized with the illness. Some of the notable characteristics of the songs were drawn from the ministry of health in the said countries and WHO, included, wash your hands, sanitizing, maintaining so cial distance, being neat, and no handshaking.

Musungu (2016) notes that the Bukusu oral narratives are performed in established and predetermined contexts. Bauman 1992:59 defines context as "the physical, mental, social surrounding which an oral narrative depends on." He posits that the relationship between oral literature and social life is deeply embedded in human events. Therefore, context plays diverse roles, such as bringing people together to learn about society and how people relate to narratives and societal expectations of people. The narration and performance of narratives involve conversational analysis such as; turn-taking, adjacency pairs, turn allocation, and turn construction. In more established narration during special functions, the performance preserves the elderly, skilled, and knowledgeable individuals.

The Bukusu verbal communications are engraved in proverbs and sayings, which are an embodiment of musical performances. The crucial role of proverbs is to educate, condemn immorality and uphold morality. During performances, elders use proverbs to show prowess and mastery of language and proficiency or eloquence. The aesthetics of this language are highly valued among Bukusu, especially during beer parties, circumcisions, and weddings, and even the payment of dowries.

Nandwa and Bukenya (1983: 85) postulate that "Song and dance pervades the whole spectrum of African traditional life. There are songs for every stage and occasion of a person's life from cradle to the grave". Music is an essential aspect of the Bukusu community's culture. Music in African communities is functional (O kafor and Emeka 1998: 141). This means that every social occasion has a specified musical performance that is acceptable in the community.

O kpewho (1990) underscores the significant role of the narrator when he posits that the narrator's ability to utilize his voice and body to convey the emotions of characters and comment on specific actions of such characters is essential for the achievement of initial aesthetic harmony with the audience. In this argument, he suggests that the narrative performance would be futile without the narrator. The role of the narrator, among other components of narration like dance and voice, is critical in communicating the intended meaning (Musungu, 2016). O kpewho further captures the opacity of songs in oral narratives when he states that "music plays an inestimable role in the oral narrative performance; and some bards. Sometimes have a tendency to indulge the musical feeling which the song interludes within the tale tend to enhance" (p.120).

Nida (1998: 29) holds the view that 'Language and culture are two symbolic systems. Everything we say in language has meanings, designative or associative, denotative or connotative. The language form we use contain meanings, that are not in the same sense since it is associated with culture and culture is more broad than language.'

Jiang 2000 argues that language simultaneously reflects the culture and is influenced and shaped by it. In the broadest sense, it is also the symbolic representation of a people since it comprises their historical and cultural backgrounds, approach to life, and ways of living and thinking (Jiang, 2000). Brown (1994:165) describes the two as follows: 'A language is a part of a culture and a culture is a part of a language; the two are intricately 
interwoven so that one cannot separate the two without losing the significance of either language or culture.' In a word, culture and language are inseparable. It is argued that language is the mirror of culture; hence, people can see cultural aspects through its language. The visible part is the language, with a small part of the culture; the more significant part, hidden beneath the surface, is the invisible aspect of culture.

\section{METHOD}

Bungoma County was selected because of the rich subjects for study, proficiency of the language, availability of the respondents, and the researcher's proximity to the site. The study adopts a convenience sampling technique. D omyei (2003) argues that in this kind of sampling, members of the target group are selected because they possess specific applicable criteria like geographical proximity and availability at a given time. Aiken (1997) adds that "convenience samples are majorly purposive because besides accessibility; subjects also possess relevant qualities for investigation and study."

The study adopts participant observation and focuses group discussions on gathering data. Patton, 1990 proposes that observation is a commonly used method, especially in studies that deal with behavioral sciences. He opines that participant observation aims to develop an insider's view of the setting and the individuals under study. Binnet 2003 adds that the method is used when data on actual cultural practices are under investigation.

Focus group discussion is also the most reliable tool to explore a target group's beliefs, attitudes, and behaviors. Therefore, natural communication on feelings, attitudes, perceptions, motives is well captured without hurting the participant's moral civility. In this study, two focus groups were created from community members, whereby one group of five members comprised the renowned elders. They are keen to perform Bukusu rituals like khuswala kumuse and khubiita. The second group comprised six clan elders from five clans: the Baluiliuili clan, Batemulani clan, Balonja clan, Baengele land, and Bakimwei clan.

\section{RESULTS AND DISCUSSION}

\section{Proverbs}

\section{Proverbs about death}

\section{Afwile kumurwe- he died the head \\ Afwile bikele - He died the legs}

The two proverbs are used interchangeably based on the context. The proverbs are primarily used in funeral functions of the deceased and elderly members of the community. The two proverbs carry symbolism drawn from body parts, i.e., the head and the legs. The head means the deceased man left behind a disorganized family, while the legs refer to a successful family after the demise of a parent.

The former means that when an older man dies and has not brought up the children morally upright. Such a proverb means that the deceased left behind a disorganized group of children who cannot make wise decisions in gatherings or are dependent upon by the family or society. It is also arguably noted that such a group of children might not have succeeded in several life spheres, such as economically, socially, or academically. Consequently, a proverb is also used to refer to the children that the deceased left who might have resorted to thuggery, robbery, theft, burglary, and many other felonies to make a living.

Therefore, if the former proverb is used in the funeral gathering of an older man, then it does also mean the dead left the children who are not level-headed. Therefore, the deceased left children who cannot be relied on in terms of the societal wellbeing of others, themselves, friends, and neighbors or relatives at large. 
The second one means the dead left behind successful children in economic emancipation and academic or professional progress. In this family, it is noted that his children can make sober decisions in festivities and social gatherings. They are dependable on many aspects of life because they are either wise/ knowledgeable or economically stable.

\section{Ali nomwana mala? D oes he have the child?}

This is the third saying on death and is quite evident in a funeral session of older men. The hidden meaning manifested in such a saying is whether the deceased left behind a child. Interestingly, even when the late had several children, people asked if he had left behind a child. G iven this leaving behind a child indicates that the elderly seek to determine whether the deceased has a reliable child from the number of the many children he had.

In this regard, within the Bukusu community, a child referred to in this wise saying is constructive, progressive, and morally upright. Furthermore, such a child might be consulted on family issues and ready to guide some issues within and outside the family parameters.

\section{Proverbs on sex}

Kumunandera kubolela wakulia- fruit tells whoever ate it

Silongo siera wasillia- clay soil killed whoever ate it

The two proverbs are cautionary, utilizing the symbolism of wild fruits and a particular type of clay soil that is always licked by cattle when they go to the riverside to drink water. The figurative language evident in the first proverb is that Kumunandera is a type of wild fruit that is poisonous that whoever eats it dies. In the second proverb, Silongo is a part of the soil always licked by cows at the riverside, just as the salt block bought from shops.

Symbolically, the two proverbs offer a warning to young people who live together, engage in sexual misconduct, reminding them that HIV/ AIDS is truly deadly. Therefore, Kumunandera and Silongo, in this context, refer to HIV-infected individuals, primarily ladies, and eating, on the other hand, is playing sex. Therefore, it is noted that those who play-acts of sex recklessly with HIV/AIDS infected individuals die at long last. Given this, individuals are advised not to move around carelessly and play sex without caution since AID S is a disease that is transmitted through acts of sex.

\section{Proverbs on wealth/ poverty}

Newenya ofwe ne kumutambo, obukula litala wacha wombakha khumeno.

If you want to die poor, put a cowshed on your teeth.

Newenya ofwe ne kumutambo obukula litala wombakha khumakusi.

If you want to die poor, build a cowshed on your testis.

The proverbs communicate a hidden meaning on the usage or expenditure of resources. The word litala in both proverbs, which refers to a cowshed, means property in land, farm produce, and livestock. In a short proverb, the paradigm (khumeno) of teeth means squandering wealth by selling it. Then spend the money to live extravagantly, or use that money to spend on hotels or restaurants to eat, and pay other bills.

The second proverb carries along with its elements of hyperbole and humor. Hyperbolically, you cannot build a cowshed on the testis, while in the same exaggeration, we find an iota of humor that leaves listeners laughing. Though it looks like an overstatement, the meaning generated is to wam and or caution men from selling the 
property in terms of land, livestock, or farm produce and then using the money for prostitution or cohabiting. This proverb is a precursor and a warning for individuals who perpetrate such a view of being spendthrifts since poverty awaits them because such a way of spending does not leave any savings.

Semantically, the two proverbs have the same meaning but vary in terms of syntactical organization. Pragmatically, they warn people from squandering the family property, which leads to poverty or someone dying poor. The final words make the fast syntactical structure different from the second one, but this does not change the morphological word-class order.

\section{Proverbs on marriage}

Sikhula sicha enju

when something grows old it goes to the house

Nokhwesa siuna okhwesa ne ndakala

When you pull a tree with branches, it comes with dirt.

The two proverbs are majorly used in marriages sessions but under varied contexts. The hidden message within the two proverbs is directed to the young who is about to marry.

In the short proverb, the young man is advised in figurative language that he should marry if he reaches marriage age. The figurative connotation in the proverb is that Sikhula (aging) means the person who is growing old. In light of this, for any young man who gets to the correct age of marriage, the proverbs in figurative language mean he should look for a house; they simply mean that he should marry.

The second proverb is both a warning and cautionary to one that intends to marry a woman who was earlier married then divorced or separated but had given birth to children. The advice provided within the proverb is that in case you marry such a woman, then such a woman will come with her children who might entirely depend on you for socio-economic welfare. The tree called siuna has many branches, and once you pull it on the road, it comes along with the dirt in terms of papers, leaves, sticks, and any other type of dirt.

Figuratively, siuna refers to the mother who gets married, while endakala (dirt) are the children that the mother comes with to the new home. The children are called dirt because, in the fast instance, they were sired by the man marrying their mother, and their upbringing might not have been proper and carry along with themselves behaviors and characters that might be a challenge to the man to deal with. The characters and behaviors that the children exude need an exposition and transparent information about their background, which might take their father some time to control them since he has little or no knowledge about it.

\section{Songs}

Circumcision songs in Bukusu land are specifically sung based on the season and even the occasion. Therefore, a cultural event like circumcision entails songs composed and sung during specific times until they initiate circumcision.

The circumcision songs are categorized into; songs that are sung when the initiate moves around playing jingles to call the relatives to witness the circumcision ceremony as the singers follow him with sticks, twigs, and simis. The second category falls in songs sung at night on the eve of circumcision. The third category is a song sung when the initiate is heading to the riverside. At the riverside, he lies in water then smeared with mud to numb the body so that the initiate does not feel pain during circumcision. Consequently, a specific song is sung when the initiate is leaving the riverside, and then after circumcision, another song is sung to celebrate.

\section{Songs are sung when the initiate/ $s$ is/ are leaving the niver}

Hoo hoo musinde wee

hoo hoo the initiate you 
Hoo hoo musinde ateremaka ache

hao hao hoo hoo

embalu yamemea khubolela ebunyolo hoo hoo the initiate fears should go to luo land

hao hao hoo hoo

circumcision is painful, I tell you

The song is sung in a jubilant and celebratory mood. It is sung when a group of people accompanies the initiate from the riverside, primarily men or young men circumcised traditionally. The circumcised young sing the song or older men. Who captures culture because of such a song should mention some traces of culture, for example, the origin of circumcision. As the initiate heads home to be circumcised, jingles are optional, and if played, they should be played with a slow rhythm.

The conditionality put forward to the initiate is that he should not blink or look side by side or backward but instead look ahead. A further requisite condition is that women and members of a community or outsiders are not allowed to be at the forefront when the initiate is getting home to be circumcised. Even the uncircumcised people are not supposed to stand in front or cross the crowd's path accompanying the initiate. The song is predominantly sung during the time the initiate is heading home to be circumcised. The singers stop singing the song as they approach the initiate's home, approximately one hundred meters away from the circumcision ground. During this period, the father or the uncle, mostly circumcised, holds the initiate's hand and accompanies him to the circumcision ground, a mall circle well marked with flour and with some pieces of magazines or papers where the initiate's blood will drop on.

The symbolism perpetuated and presented in the song is that those who fear circumcision should believe that people do not get circumcised like Luo land or any place. Therefore, the song discourages acts of cowardice among the youths and teaches the youths the history of Bukusu circumcision.

\section{A song sang when the initiate is heading to the river}

Bachonga hao hao bachonga

Musinde hao orao bachonga

Bachonga musinde hao

Eeh orao bachonga

$$
\begin{aligned}
& \text { sharpen hao hao sharpen } \\
& \text { the initiate hao put it be sharpened } \\
& \text { they sharpen the initiate hao } \\
& \text { eeh put there it will be sharpened }
\end{aligned}
$$

A song sang when the initiate is heading the riverside to be smeared with mud. Young men or older men who are circumcised traditionally sing the song, while the initiate plays jingles heading to the riverside. The initiate is mostly half-naked with a short, and a piece of meat cut from the cows' rumen is placed in the neck, and the entire body is smeared with cow dung.

The symbolism and figurative language manifested in the song urge the initiate to be courageous during circumcision. In addition, the song means that the initiate should 'allow the circumciser to sharpen his genitals,

' which means the initiate should withstand the actual act of circumcision or allow the circumciser to operate.

\section{A song is sung when calling relatives or on the eve of circumcision}

Many songs are sung during this period, but here, the highlight is on one particular song that is notoriously singing to castigate some vice.

Helen komanda akomanda sikuli nekera babaandu

Helen is ahead of a school but heads the school and kills people

Babuya ekholo embi kumusinde babuya is a bad tribe 
O khatima wayila omukhana mubuya don't marry a girl from babuya clan

Babandu khu chwele khuenja chikura ne wafukho munchu kekhale khungubo people at chwele look for votes then the mole is sitting on clothes

The song condemns one woman from a clan called babuya, which practices witchcraft. However, the song ridicules the woman's behavior, but the caution is on the whole clan or any other community with a debased character. It castigates behaviors of clans that are noted of harboring witches, and the community uses the occasion of circumcision in such huge gatherings to condemn such a vice.

The song also focuses on babuya, a community that rears wild animals such as a mole for witchcraft purposes. The song talks of a school principal, who hails from the tribe of babuya, who leads the school then kills people. The initiate is warned not to marry from such a community that kills people. Although the song is sung during the circumcision period and only focuses on one community to communicate the idea, this might be a message to the entire Bukusu nation to rebuke, castigate, condemn and shun such an outrageous behavior of witchcraft.

\section{CONCLUSION}

From the preceding discussion, song, dance and proverbs are core aspects of culture within the Bukusu community. It can be conclusively argued that the language of songs and proverbs, as manifested in some cultural occasions, can be figurative during a performance. The community has a well-laid set of songs sung and performed during specific sessions during the circumcision period. The songs encouraged the initiates to face the knife of circumcision and even condemned public members' irresponsible and somewhat inappropriate behavior. The language of proverbs and sayings is symbolic. Like other communities, only the members have the preserve and audacity to understand and interpret the proverbs. Recommendation; This paper has focused on isolated cases of proverbs evident in Bukusu cultural festivities. It is evidenced that the discussion raised here about proverbs is majorly a piece of advice and warning to the members of the society of issues about both social and economic spheres of life. Based on the discussion, the researcher proposes that research on a specific categorization of proverbs should be carried out to unearth the underlying functions, semantics, and structure of proverbs in various festivals. The study also suggests that songs in each community as cultural markers should be studied in conjunction with dances and accompaniments that make the festival lively for newcomers and participants.

\section{REFERENCES}

Aiken, L. R., \& Aiken, L. R. (1997). Q uestionnaires and inventories: Surveying opinions and assessing personality. N ew Y ork: J. Wiley. [G oogle Search] [Google Scholar] [G oogle Books]

Angogo, R. M. (1980). Linguistic and attitudinal factors in the maintenance of Luyia group identity. The University of Texas at Austin. [Google Search] [G oogle Scholar] [Google Books]

Bauman, R. (Ed.). (1992). Folklore, cultural performances, and popular entertainments: A communicationscentered handbook. Oxford University Press. [G oogle Search] [G oogle Scholar] [G oogle Books]

Brown, H. D. (2000). Principles of language learning and teaching (Vol. 4). New York: Longman. [Google Search] [G oogle Scholar] [Google Books]

Dömyei, Z., \& Taguchi, T. (2009). Q uestionnaires in second language research: Construction, administration, and processing. Routledge. [G oogle Search] [G oogle Scholar] [G oogle Books]

Holtgraves, T. M., \& Kashima, Y. (2007). Language, Meaning, and Social Cognition. Personality and Social Psychology Review, 12(1), 73-94. https:/ / doi.org/ 10.1177/ 1088868307309605 [G oogle Search] [G oogle Scholar] [Google Books] [Publisher website] 
Jafari, S. M and Mahadi, T, S. (2012). Language and Culture International Journal of Humanities and Social Science Vol. 2 No. 17; September 2012 230. [G oogle Search] [Google Scholar] [G oogle Books]

Jiang, W. (2000). The relationship between culture and language. ELT Journal, 54(4), 328-334. https:/ / doi.org/ 10.1093/ elt/ 54.4.328 [G oogle Search] [G oogle Scholar] [G oogle Books] [Publisher website]

Maelo, M Moi University The Context and Structure of Funeral O ratory among the Bukusu volume 19, Issue 12, Ver. III (D ec. 2014), P.P. 30-39. www.iosrjournals.org www.iosrjournals.org. [G oogle Search] [Google Scholar] [Google Books]

Musungu, J. M. (2016). O ral Narrative Performance and the Construction of Bukusu Perceptions on Communal Coexistence. Ph.D. dissertation. University of Nairobi. [G oogle Search] [G oogle Scholar] [Google Books]

Naituli, G , J , King'ori N, S. 2012. An examination of ethnic stereotypes and coded language used in Kenya and its implication for national cohesion International Journal of Humanities and Social Science Vol. 2 No. 17; September 2012 230. [G oogle Search] [G oogle Scholar] [G oogle Books]

Nandelenga H. S. (2013). Constraint Interaction in the Syllabic Phonology of Lubukusu: An Optimality Theory Account. Ph.D. Thesis, Kenyatta University. [G oogle Search] [G oogle Scholar] [G oogle Books]

Nandwa, J, and Bukenya, A. (1983). African O ral Literature for Schools. Nairobi: Longman. [G oogle Search] [G oogle Scholar] [Google Books]

Nida, E. (1998). 'Language, culture, and translation.' Foreign Languages Journal 115/ 3: 29-33. [G oogle Search] [G oogle Scholar] [Google Books]

O kafor, R, C and Emeka. L, N. ed. 1998. Nigerian peoples and culture. Enugu, Nigeria: General Studies Division, Enugu State University of Science and Technology. [G oogle Search] [Google Scholar] [Google Books]

O kpewho, I. (Ed). (1990). The O ral Performance in Africa. Ibadan: Spectrum Books Limited. [Google Search] [G oogle Scholar] [Google Books]

Thompson, R. G . A., Nutor, J. J., \& Johnson, J. K. (2021). Communicating A wareness About COVID-19 Through Songs: An Example From G hana. Frontiers in Public Health, 8, 607830. https:/ / doi.org/ 10.3389/ fpubh.2020.607830 [G oogle Search] [G oogle Scholar] [G oogle Books] [Publisher website]

Wasambo, W, (2009). A Traditional Ritual Ceremony as Edurama: A Case Study of Imbalu Ritual among the Bukusu of Western Kenya, Ph.D. Thesis. Kenyatta University. [G oogle Search] [G oogle Scholar] [Google Books]

Watera, M. (2014). Morphophonological Changes of Borrowed Words from English to Lubukusu Dialect of Western Kenya. International Journal of English and Literature, vol 5 (2) pp45-51. [Google Search] [G oogle Scholar] [G oogle Books] 